\title{
THE VALIDITY OF PURCHASING POWER PARITY IN THE BRICS COUNTRIES
}

\section{Burak Güriş, Muhammed Tiraşoğlu*}

\begin{abstract}
It is observed that purchasing power parity (PPP) as one of the controversial and most interesting topics of international macroeconomics literature is tested by using different econometric methods for certain countries and/or country groups by many researchers. The validity of PPP is important in terms of being a common exchange rate used in international comparison. In this context, the validity of relative purchasing power parities in the BRICS countries (Brazil, Russia, India, China and South Africa) were analysed for the January 1993-March 2015 period. Non-linear stationarity analysis was used in the study. According to the findings of the analysis, it was concluded that all of the BRICS countries have a non-linear structure; the PPP approach was valid for Brazil and South Africa, but not valid for Russia, India and China in the relevant period.
\end{abstract}

Keywords: purchasing power parity, BRICS countries, Fourier stationary test, nonlinearity JEL Classification: C22, F31

\section{Introduction}

The exchange rates that have an important place in the economic structure of countries and the different approaches to exchange rates have drawn an attention of many researchers and policy makers. A common approach in literature to currency exchange rates is the analysis of the validity of purchasing power parity. The importance of the purchasing power parity (PPP) first introduced by the Swedish economist Gustav Cassel (1918) has started to increase after the collapse of the Bretton Woods system and the fluctuation of the exchange rates.

PPP has been one of the controversial issues of international economics especially since the 1970s. PPP as one of the indicators used in the comparison of the levels of development between countries is the equation between the increase in the rate of foreign currency and the difference in inflation between the domestic and foreign country. Of course, high inflation rates reduce the value of the currency of the country (Enders and Falk, 1998). If expressed in a common currency, PPP offers the necessary adjustments to market exchange rates in order for the price of an item to be identical as in two countries (Majumder, Ray and Sinha, 2011).

PPP can be defined under two subtitles as absolute and relative purchasing power parity. Absolute PPP refers to the fact that purchasing power of the domestic currency is the same in foreign countries. Relative PPP means a proportional change of nominal exchange rates corresponding to relevant currencies against changes in national price levels (Coakley et al., 2005). Due to the complex structure of the economy and differences between nations, it is seen that relative PPP is more commonly used in studies.

* Burak Güriş, Faculty of Economics, Istanbul University, Istanbul, Turkey (bguris@istanbul.edu.tr); Muhammed Tiraşoğlu, Faculty of Economics and Administrative Sciences, Kırklareli Universty, Kırklareli, Turkey (muhammedtirasoglu@klu.edu.tr). 
It is observed that there is a wide range of literature related to the PPP theory that is examined and still being explored by many researchers for countries or country groups. Some of the prominent studies in the literature are Roll (1979), Adler and Lehmann (1983), Dornbush (1985), Rogoff (1996), Papell (1997), Sarno and Taylor (1998), Culver and Papell (1999), Lothian and Taylor (2000), Cheung and Lai (2001), Kapetanios, Shin, Snell (2003), Taylor and Taylor (2004), Taylor (2006), Cerrato and Sarantis (2007), Lothian and Taylor (2008), Bahmani-Oskooee, Hegerty and Ku (2009), Zhou and Ku (2011), BahmaniOskooee, Chang and Hung (2013), the Bahmani-Oskooee, Chang and Wu (2015).

In their study, Froot and Rogoff (1994) stressed that there are three different stages in the analysis of the validity of PPP: (i) old tests showing the validity of PPP under basic hypothesis; (ii) PPP completely permanent under basic hypothesis with newer methods and time series tests; (iii) the linear combination of the exchange rate and the price permanent under basic hypothesis with much newer techniques such as co-integration tests.

The validity of PPP refers to the fact that real exchange rates are permanent in the long term by having a mean reversion. If the changes that occur in the price levels do not change the nominal exchange rate at the same rate, the real exchange rates will not tend to gravitate to the value of the equilibrium in the end. PPP validity depends on several phenomena; PPP model does not take into account the transportation cost and tariffs; the sticky prices do not allow efficient market hypothesis and use of different goods baskets for the index calculation. There are different techniques for the exploration of mean reversion in real exchange rate. The most common of these techniques are the unit root tests testing the stability of real exchange rates. It is observed in literature that the validity of PPP is examined by using linear, structural breaks, non-linear and panel unit root tests in accordance with the structure of the classified series.

The method frequently used to test PPP empirically is the use of unit root tests. If the realexchange rate is stationary, the shocks will have a temporal effect. If the real exchange rate contains a unit root, then the shocks will have a permanent effect. This means that the purchasing power parity is invalid (Cuestas and Regis, 2013). The validity of PPP for the BRICS (Brazil, Russia, India, China and South Africa) countries was analysed by using Becker, Enders and Lee (2006) nonlinear stationary test. Becker, Enders and Lee (2006) suggested a KPSS type nonlinear stationary test, and they used trigonometric terms to capture unknown nonlinearities with the Fourier approximation. The reason for preferring these tests is that the transition between regimes considered to be more appropriate for the economic structure is smooth and has a better power than previous tests. According to our knowledge, there are no other studies that examine the validity of the purchasing power parity in the BRICS countries by using this method.

The BRICS countries have an important place among country groups and the world economy. The BRICS countries have approximately $26 \%$ of the world land area. However, this country group with a young and dynamic population has nearly $40 \%$ of the world's population. According to 2014 data, combined nominal GDP of these five countries is equivalent to $20 \%$ of world GDP. Another important feature of the BRICS is their projection of building a new Development Bank with $\$ 100$ billion reserve as a competitor to the World Bank. For this purpose, empirical studies about the PPP of the BRICS countries will be examined after giving 
information about the PPP. After that, the econometric method that will be used in the analysis of the validity of PPP for the BRICS countries will be introduced and its importance will be highlighted. Finally, the findings of the econometric study will be evaluated.

\section{Literature Review}

The validity of PPP theory is analysed for different countries and/or country groups by using econometrics and time-series methods. It is observed that different results are obtained in empirical studies. The main reasons for this are that the period under review is different, the econometric method used in the review and the tests of this method differ from each other, the types of price indexes are different from each other, etc. Table 1 shows the empirical studies regarding the validity of PPP in the BRICS countries. When the table related to literature review is examined, it is observed that there is no common decision about the validity of PPP.

Table 1 | Literature about the BRICS Countries

\begin{tabular}{|c|c|c|c|c|}
\hline Author & Countries & Data Range & Method & Finding \\
\hline $\begin{array}{l}\text { Su, Horng and } \\
\text { Wu (2008) }\end{array}$ & BRIC & $\begin{array}{l}\text { June 1992- } \\
\text { December } 2006\end{array}$ & $\begin{array}{l}\text { Linear and Nonlinear } \\
\text { Cointegration test }\end{array}$ & $\begin{array}{l}\text { PPP is not valid in Linear } \\
\text { Cointegration, PPP is only valid } \\
\text { for China in Nonliear } \\
\text { Cointegration }\end{array}$ \\
\hline $\begin{array}{l}\text { Bahmani- } \\
\text { Oskooee } \\
\text { Hegerty and } \\
\text { Kutan (2009) }\end{array}$ & $\begin{array}{l}52 \\
\text { Country }\end{array}$ & $\begin{array}{l}\text { January 1994- } \\
\text { June } 2007\end{array}$ & Unit root test & $\begin{array}{l}\text { PPP is only valid for China and } \\
\text { India }\end{array}$ \\
\hline $\begin{array}{l}\text { Chang, Su, Zhu, } \\
\text { and Liu (2010) }\end{array}$ & BRIC & $\begin{array}{l}\text { July 1992- } \\
\text { December } 2006\end{array}$ & $\begin{array}{l}\text { Linear and Nonlinear } \\
\text { Cointegration test }\end{array}$ & $\begin{array}{l}\text { PPP is not valid for China, PPP } \\
\text { is valid for others countries }\end{array}$ \\
\hline $\begin{array}{l}\text { Chang, Lee and } \\
\text { Hung (2012) }\end{array}$ & BRIC & $\begin{array}{l}\text { January 1996- } \\
\text { July } 2010\end{array}$ & $\begin{array}{l}\text { Nonlinear } \\
\text { Cointegration test }\end{array}$ & $\begin{array}{l}\text { PPP is not valid for Brazil, PPP } \\
\text { is valid for others }\end{array}$ \\
\hline $\begin{array}{l}\text { Su, Chang, } \\
\text { Chang and Lee } \\
(2012)\end{array}$ & BRIC & $\begin{array}{l}\text { January 1996- } \\
\text { July } 2010\end{array}$ & $\begin{array}{l}\text { Nonlinear unit root } \\
\text { test }\end{array}$ & PPP is valid for all countries \\
\hline $\begin{array}{l}\text { Bahmani- } \\
\text { Oskooee Chang } \\
\text { and Lee (2014) }\end{array}$ & BRIC & $\begin{array}{l}\text { January 1994- } \\
\text { June } 2012\end{array}$ & $\begin{array}{l}\text { Linear, Nonlinear and } \\
\text { Panel unit root tests }\end{array}$ & Mixed results \\
\hline $\begin{array}{l}\text { Baghestani } \\
\text { (1997) }\end{array}$ & India & 1973-1991 & $\begin{array}{l}\text { Linear Cointegration } \\
\text { test }\end{array}$ & PPP is valid \\
\hline $\begin{array}{l}\text { Bahmani- } \\
\text { Oskooee and } \\
\text { Barry (1997) }\end{array}$ & Russia & $\begin{array}{l}\text { May 1991- } \\
\text { March } 1995\end{array}$ & $\begin{array}{l}\text { Linear Cointegration } \\
\text { tests }\end{array}$ & PPP is valid \\
\hline $\begin{array}{l}\text { Guimaraes- } \\
\text { Filho (1999) }\end{array}$ & Brazil & $1855-1990$ & Unit root tests & PPP is valid \\
\hline $\begin{array}{l}\text { Alves, Cati and } \\
\text { Fava (2001) }\end{array}$ & Brazil & $1855-1996$ & Cointegration test & PPP is not valid \\
\hline $\begin{array}{l}\text { Caporale and } \\
\text { Gil-Alana } \\
(2010)\end{array}$ & $\begin{array}{l}\text { South } \\
\text { Africa }\end{array}$ & $\begin{array}{l}\text { 1990-2008 } \\
\text { Daily, Weekly, } \\
\text { Monthly data }\end{array}$ & Unit root test & PPP is not valid \\
\hline $\begin{array}{l}\text { Gregory and } \\
\text { Shelley (2011) }\end{array}$ & China & $\begin{array}{l}\text { January } \\
\text { 1986-September } \\
2006\end{array}$ & Unit root tests & PPP is not valid \\
\hline
\end{tabular}

Source: Authors. 


\section{Data and Methodology}

The validity of PPP for the BRICS (Brazil, Russia, India, China and South Africa) countries was analysed by using the new time series methods. The relevant series in the study are monthly data covering the January 1993-March 2015 period and the KPSS stationarity test developed by Kwiatkowski et al. (1992) and the Fourier stationarity test developed by Beckers, Enders, and Lee (2006) were used. The data that are used in the analysis have been obtained from the OECD data and all series are used in logarithmic form. The real exchange rates series for the validity of PPP are obtained from the Equation 1.

$$
y_{i, t}=s_{i, t}+p_{u s, t}-p_{i, t}
$$

Here $y_{i, t}$ represents the logarithmic real exchange rates, $s_{i, t}$ represents the logarithmic nominal exchange rate (units of domestic currency per U.S. dollar), $p_{u s, t}$ represents the logarithmic price index (US), and $p_{i, t}$ represents the $i$ country's logarithmic price index.

The method frequently used to test PPP empirically is the use of unit root tests. Unit root test or stationary test is a crucial issue in time series analysis for an empirical study. The basic problem experienced in unit root tests is that the correct model specification cannot be determined. Enders and Granger (1998) demonstrate that the standard tests for unit root and cointegration all have lower power in the presence of misspecified dynamics. Perron (1989) showed that when the existing structural break ignored the conventional unit root tests, it will be biased towards not rejecting a false null of a unit root. A similar phenomenon occurs in nonlinear models. If the data are nonlinear, then the linear unit root tests will face the problem of power. These test results will be the non-rejection of the null hypothesis and biased (Cuestas and Garrant, 2011).

A lot of unit root tests have been developed for nonlinear time series analysis (e.g. Enders and Granger (1998), Leybourne, Newbold and Vougas (1998), Caner and Hansen (2001), Kapetanios, Shin and Snell (2003) and Park and Shintani (2005)). Becker, Enders and Lee (2006) developed a nonlinear stationary test with the Fourier function. They suggested a KPSS type nonlinear stationary test, and they used trigonometric terms to capture unknown nonlinearities with the Fourier approximation.

Following the Becker, Enders and Lee (2006) study, the data generating process (DGP) is

$$
\begin{aligned}
& y_{t}=X_{t}^{\prime} \beta+Z_{t}^{\prime} \gamma+r_{t}+\varepsilon_{t} \\
& r_{t}=r_{t-1}+u_{t}
\end{aligned}
$$

where $\varepsilon_{t}$ and denotes respectively, stationary errors and iid with variance $\sigma_{u}^{2}$. They suggested $Z_{t}=[\sin (2 \pi k t / T), \cos (2 \pi k t / T)]^{\prime}$ to capture a break in the deterministic term. Here, $k$ represents the number of frequencies and $T$ is sample size. Following the Becker, Enders and Lee (2006), we consider the following Fourier series;

$$
\alpha(t)=\alpha_{0}+\sum_{k=1}^{n} \alpha_{k} \sin \left(\frac{2 \pi k t}{T}\right)+\sum_{k=1}^{n} b_{k} \cos \left(\frac{2 \pi k t}{T}\right) ; \quad n<\frac{T}{2}
$$


where $n$ shows the number of frequencies contained in the approximation (Becker, Enders and Lee, 2006). They suggest the two following regressions and where $\tilde{e}_{t}$ denote residuals;

$$
\begin{gathered}
y_{t}=\alpha+\gamma_{1} \sin \left(\frac{2 \pi k t}{T}\right)+\gamma_{2} \cos \left(\frac{2 \pi k t}{T}\right)+e_{t} \\
y_{t}=\alpha+\beta_{t}+\gamma_{1} \sin \left(\frac{2 \pi k t}{T}\right)+\gamma_{2} \cos \left(\frac{2 \pi k t}{T}\right)+e_{t}
\end{gathered}
$$

While Equation 4 tests the null of level stationary, Equation 5 tests the null of trend stationary (Chang, 2011). The Fourier stationary test statistics $\tau_{\mu}(k)$ or $\tau_{\tau}(k)$ for Equation 4 and Equation 5;

$$
\tau_{\mu}(k) \text { or } \tau_{\tau}(k)=\frac{1}{T^{2}} \frac{\sum_{t=1}^{T} \tilde{S}_{t}(k)^{2}}{\hat{\sigma}^{2}}
$$

where $\tilde{S}_{t}(k)=\sum_{j}^{t} \tilde{e}_{j}$ and $\tilde{e}_{j}$ represents OLS residuals from the Equation 4 and Equation 5, respectively. They suggest that a nonparametric estimate of as in KPSS;

$$
\tilde{\sigma}^{2}=\tilde{\gamma}_{0}+2 \sum w_{j} \tilde{\gamma}_{j}
$$

where $\tilde{\gamma}_{j}$ is the $j$-th sample autocovariance of residual from Equation 4 and Equation 5, respectively (Becker, Enders and Lee, 2006). They obtained a critical value for their stationary test with the aid of Monte Carlo simulations, which is $k$ between $1, \ldots, 5$ and sample size (T) of 100, 500 and 1000 observations. They tabulated the critical values of the linearity test and stationary test in their study.

In the case where there is no non-linear trend, a standard KPSS test will be stronger. For this reason, the lack of a non-linear trend must be tested. Becker, Enders and Lee (2006) suggest the following F-test statistics calculated against the alternative nonlinear trend with a given frequency $k$

$$
F_{i}(k)=\frac{\left(\operatorname{SSR}_{0}-\operatorname{SSR}_{1}(k)\right) / 2}{\operatorname{SSR}_{1}(k) /(T-q)} \quad i=\mu, \tau
$$

where $S S R_{0}$ denotes the SSR from regression without the trigonometric terms, $\operatorname{SSR}_{1}(k)$ denotes the SSR from Equation 2 or 3 and $q$ is the number of regressors. The distribution of $F$ test is non standard when the null of stationary is rejected. From this viewpoint, the critical values to be used were tabulated in the study of Becker, Enders and Lee (2006).

\section{Empirical Results}

The validity of PPP shows that real exchange rates tend to have a mean reversion. The most common techniques that can be used whether real exchange rate had a mean reversion are the unit root tests for the exploration of the stability of real exchange rates.

As discussed in the econometric methodology section, the Fourier stationary test developed by Becker, Enders and Lee (2006) is used for testing the validity of PPP in BRICS countries. The standard KPSS test and the Fourier stationarity test results are shown in Table 2. 


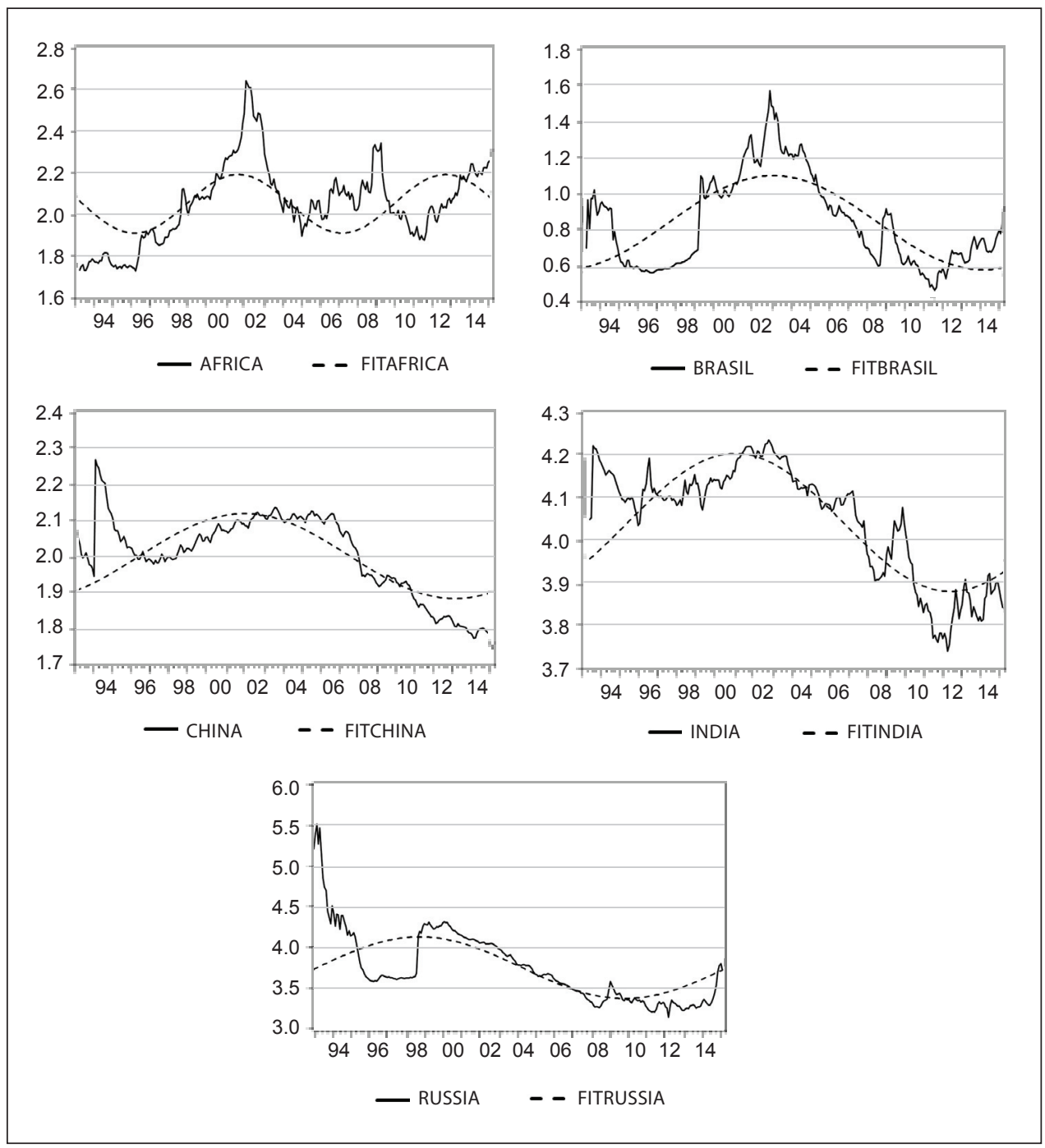

Source: Author's calculations.

$F_{\mu}(\hat{k})$ test statistics are reported in Table 2 showing that the null hypothesis of linearity is rejected in all series. Given these findings, the null hypothesis of stationarity can be tested using the Fourier stationarity test. According to the results in Table $2, \tau_{\mu}(\hat{k})$ the test statistics indicate that the null hypothesis of stationarity is accepted for Brazil and South Africa, while it is rejected for China, India and Russia. Additionally, as can be seen in Figure 1, the Fourier approximations can fit well. The empirical results imply that PPP holds true for Brazil and South Africa but not for China, India and Russia. 
Table 2 | Tests for Stationarity in BRICS Countries

\begin{tabular}{|l|c|c|c|c|}
\hline & $\operatorname{KPSS}\left(\tau_{K P S S}\right)$ & $k$ & $F_{\mu}(\hat{k})$ & $\tau_{\mu}(\hat{k})$ \\
\hline Brazil & $0.567332(8)$ & 1 & $154.75415^{\mathrm{a}}$ & $0.15492^{*}$ \\
\hline China & $1.71587(8)$ & 1 & $156.02515^{\mathrm{a}}$ & 0.84503 \\
\hline India & $2.23465(8)$ & 1 & $330.77571^{\mathrm{a}}$ & 0.67549 \\
\hline Russia & $1.93752(8)$ & 1 & $76.60438^{\mathrm{a}}$ & 0.45296 \\
\hline South Africa & $0.783312(8)$ & 2 & $50.00598^{\mathrm{a}}$ & $0.5211^{*}$ \\
\hline
\end{tabular}

Note: $\left(\tau_{K P S S}\right)$ is the value of standard KPSS test for the null hypothesis of stationary. The figures in parentheses are optimal lag length. The critical values for KPSS test are $0.739,0.463,0.345$ at $1 \%, 5 \%, 10 \%$ significance level, respectively. ${ }^{a, b, c}$ denotes the null hypothesis of linearity are rejected at $1 \%, 5 \%, 10 \%$ significance level, respectively. ${ }^{* * *, * * *}$ denotes that PPP are supported at significance level, respectively.

Source: Author's calculations.

\section{Conclusions}

In this study, the intention was to test the validity of PPP in the BRICS countries that have an important place in the world economy. The validity of PPP as a frequent subject of empirical studies was tested using the Fourier stationarity tests. According to the findings, there is a non-linear structure for all countries. The results obtained in this context show that PPP is valid for Brazil and South Africa and not valid for China, India and Russia. It can be argued that deviations from the real exchange rate are permanent in countries where there is no validity of PPP. The exchange rate policies implemented in these countries will not have an effect on national economy, exchange rate changes will not be stable and therefore economic stability will be affected in a negative way.

The factors that have an impact on the invalidity of PPP could be listed as follows: differences in price indexes, use of different goods baskets for the index calculation, the transport costs that have an impact on the price levels of two countries, customs taxes, administrative regulations and tariffs. In addition to these, the growth and efficiency differences between the BRICS countries and the USA are also important factors. Therefore, the policymakers of China, India and Russia should take these characteristics into consideration and develop policies accordingly. This conclusion implies that deviation from PPP is permanent. The policymakers of Brazil and South Africa will be able to implement monetary policies to preserve the value of their national currencies by developing foreign trade strategies based on PPP and by deciding on the optimum level of foreign exchange currency. The countries follow these policies as long as PPP will be valid in future.

In addition to the abovementioned factors, the economic and political conditions of the BRICS countries specific to the country in question have an effect on the results testing the validity of PPP. Contrary to the situation in Brazil and South Africa, using the exchange rate policies in India and China as a more active foreign trade tool, especially 
during the 2009 economic crisis and later, had an effect on the validity of PPP. On the other hand, the volatility of natural resources, which are the most important foreign exchange resource for Russia, might have had an effect on the validity of PPP. However, detailed analysis of the economic and political conditions of these countries is beyond the purpose and scope of this paper.

\section{References}

Adler, M., Lehmann, B. (1983). Deviations from Purchasing Power Parity in the Long Run. The Journal of Finance, 38(5), 1471-1487, https://doi.org/10.2307/2327581

Alves, D. C. O., Cati, R. C., Fava, V. L. (2001). Purchasing Power Parity in Brazil: A Test for Fractional Cointegration. Applied Economics, 33(9), 1175-1185, https://doi.org/10.1080/00036840122819

Baghestani, H. (1997). Purchasing Power Parity in the Presence of Foreign Exchange Black Markets: The case of India. Applied Economics, 29(9), 1147-1154, https://doi.org/10.1080/00036849700000005

Bahmani-Oskooee, M., Barry, M. (1997). The Purchasing Power Parity and the Russian Ruble. Comparative Economic Studies, 39(1), 82-94, https://doi.org/10.1057/ces.1997.4

Bahmani-Oskooee, M., Hegerty, S., Kutan, A. M. (2009). Is PPP Sensitive to Time-Varying Trade Weights in Constructing Real Effective Exchange Rates? The Quarterly Review of Economics and Finance, 49(3), 1001-1008, https://doi.org/10.1016/j.qref.2008.09.001

Bahmani-Oskooee, M., Chang, T., Hung, K. (2013). Revisiting Purchasing Power Parity in Latin America: Sequental Panel Selection Method. Applied Economics, 45(32), 4584-4590, https://doi.org/10.1080/00036846.2013.795279

Bahmani-Oskooee, M., Chang, T., Lee, K. (2014). Purchasing Power Parity in the BRICS and the MIST Countries: Sequential Panel Selection Method. Review of Economics \& Finance, 4, 1-12.

Bahmani-Oskooee, M., Chang, T. Wu, T. (2015). Purchasing Power Parity in Transition Countries: Panel Stationary Test with Smooth and Sharp Breaks. International Journal of Financial Studies, 3(2), 153-161, https://doi.org/10.3390/ijfs3020153

Becker, R., Enders, W., Lee, J. (2006). A Stationary Test in the Presence of an Unknown Number of Smooth Breaks. Journal of Time Series Analysis, 27(3), 381-409, https://doi.org/10.1111/j.1467-9892.2006.00478.x

Caner, M., Hansen, B. E. (2001). Threshold Autoregression with a Unit Root. Econometrica, 69(6), 1555-1556, https://doi.org/10.1111/1468-0262.00257

Caporale, G. M., Gil-Alana, L. A. (2010). Testing PPP for the South African Rand/US Dollar Exchange Rate at Different Frequencies. Brunel University Department of Economics and Finance Working Paper, 10-11.

Cassel, G. (1918). Abnormal Deviations in International Exchanges. The Economic Journal, 28(112), 413-415, https://doi.org/10.2307/2223329

Cerrato, M., Sarantis, N. (2007). Does Purchasing Power Parity Hold in Emerging Markets? Evidence from a Panel of Black Market Exchange Rates. International Journal of Finance \& Economics, 12(4), 427-444, https://doi.org/10.1002/ijfe.318

Chang, H., Su, C., Zhu, M., Liu, P. (2010). Long-run Purchasing Power Parity and Asymetric Adjustment in BRICs. Applied Economics Letters, 17(11), 1083-1087, https://doi. org/10.1080/00036840902817458 
Chang, T., Lee, C., Hung, K. (2012). Can the PPP Stand on the BRICS? The ADL Test for Threshold Cointegration. Applied Economics Letters, 19(12), 1123-1127, https://doi.org/10.1080/135 04851.2011 .615727

Cheung, Y., Lai, K. S. (2001). Long Memory and Nonlinear Mean Reversion in Japanese Yen-Based Real Exchange Rates. Journal of International Money and Finance, 20(1), 115-132, https://doi.org/10.1016/s0261-5606(00)00037-1

Coakley, J., Flood R. P., Fuertes A. M., Taylor, M. P. (2005). Purchasing Power Parity and the Theory of General Relativity: The First Tests. Journal of International Money and Finance, 24(2), 293-316, https://doi.org/10.1016/j.jimonfin.2004.12.008

Crownover, C., Pippenger, J., Steigerwald, D. G. (1996). Testing for Absolute Purchasing Power Parity. Journal of International Money and Finance, 15(5), 783-796, https://doi.org/10.1016/0261-5606(96)00035-6

Cuestas J.C., Garratt, D. (2011). Is Real GDP per capita a Stationary Process? Smooth Transitions, Nonlinear Trends and Unit Root Testing. Empirical Economics, 41 (3), 555-563, https://doi.org/10.1007/s00181-010-0389-0

Cuestas J. C., Regis, P. J. (2013). Purchasing Power Parity in OECD Countries: Nonlinear Unit Root Tests Revisited. Economic Modelling, 32, 343-346, https://doi.org/10.1016/j. econmod.2013.01.035

Culver, S. E., Papell, D. H. (1999). Long-Run Purchasing Power Parity with Short-Run Data: Evidence with A Null Hypothesis of Stationary. Journal of International Money and Finance, 18(5), 751-768, https://doi.org/10.1016/s0261-5606(99)00028-5

Dornbusch, R. (1985). Purchasing Power Parity. NBER. Working Paper Series No.1591.

Enders, W., Falk, B. (1998). Threshold-Autoregressive, Median-Unbiased, and Cointegration Tests of Purchasing Power Parity. International Journal of Forecasting, 14(2), 171-186, https://doi.org/10.1016/s0169-2070(98)00025-9

Enders, W., Granger, C. W. J. (1998). Unit-Root Tests and Asymmetric Adjustment with an Example Using the Term Structure of Interest Rates. Journal of Business \& Economic Statistics, 16(3), 304-311, https://doi.org/10.2307/1392506

Froot, A. K., Rogoff, K. (1994). Perspectives on PPP and Long-Run Real Exchange Rates. NBER. Working Paper Series No. 4952, https://doi.org/10.3386/w4952

Gregory, R. P., Shelley, G. (2011). Purchasing Power Parity and the Chinese Yuan. Economics Bulletin, 31(2), 1247-1255.

Guimaraes-Filho, R. F. (1999). Does Purchasing Power Parity Hold after All? Evidence from a Robust Test. Applied Financial Economics, 9(2), 162-172, https://doi. org/10.1080/096031099332429

Hakkio, C. S. (1992). Is Purchasing Power Parity a Useful Guide to the Dollar. Economic ReviewFederal Reserve Bank of Kansas City, 77, 37-51.

Kapetanios, G., Shin, Y., Snell, A. (2003). Testing for a Unit Root in the Nonlinear STAR Framework. Journal of Econometrics, 112(2), 359-379, https://doi.org/10.1016/ s0304-4076(02)00202-6

Kwiatkowski, D., Phillips, P. C. B., Schmidt, P., Shin, Y. (1992). Testing the Null Hypothesis of Stationarity against the Alternative of a Unit Root. Journal of Econometrics, 54(1-3), 159-178, https://doi.org/10.1016/0304-4076(92)90104-y

Leybourne, S., Newbold, P., Vougas, D. (1998). Unit Roots and Smooth Transitions. Journal of Time Series Analysis, 19(1), 83-97, https://doi.org/10.1111/1467-9892.00078 
Lothian, J. R., Taylor, M. P. (2000). Purchasing Power Parity over Two Centuries: Strengthening the Case for Real Exchange Rate Stability: A Reply to Cuddington and Liang. Journal of International Money and Finance, 19(5), 759-764, https://doi.org/10.1016/ s0261-5606(00)00030-9

Lothian, J. R., Taylor, M. P. (2008). Real Exchange Rate over the Past Two Centuries: How Import Is the Harrod-Balassa-Samuelson Effect? The Economic Journal, 118(532), 1742-1763, https://doi.org/10.1111/j.1468-0297.2008.02188.x

Majumder, A., Ray, R., Sinha, K. (2011). Estimating Intra Country and Cross Country Purchasing Power Parities from Household Expenditure Data Using Single Equation and Complete Demand Systems Approach: India and Vietnam. Monash University Department of Economics. Discussion Paper No. 34/11.

Papell, D. H. (1997). Searching for Stationary: Purchasing Power Parity under the Current Float. Journal of International Economics, 43(3-4), 313-332, https://doi.org/10.1016/ s0022-1996(96)01467-5

Park, J. Y., Shintani, M. (2005). Testing for a Unit Root against Transitional Autoregressive Models. Vanderbilt University Department of Economics. Working Papers No. 05-W10.

Rogoff, K. (1996). The Purchasing Power Parity Puzzle. Journal of Economic Literature, 34, 647-668.

Roll, R. (1979). Violations of Purchasing Power Parity and their Implations for Efficient International Commodity Markets, in Sarnat, M., Szego, G., ed., International Finance and Trade. Ballinger, Cambridge: MA, 133-176.

Sarno, L., Taylor, M. P. (1998). Real Exchange Rates under the Recent Float: Unequivocal Evidence of Mean Reversion. Economics Letters, 60(2), 131-137, https://doi.org/10.1016/ s0165-1765(98)00106-2

Su, C., Chang, H., Chang, T., Lee, C. (2012). Purchasing Power Parity for BRICS: Linear and Nonlinear Unit Root Tests with Stationary Covariates. Applied Economics Letters, 19(16), 1587-1591, https://doi.org/10.1080/13504851.2011.639732

Su, C., Horng, Y., Wu, Y. Asymmetric Adjustment and Long-Run Purchasing Power Parity in BRICs. Available at: [http://bioagri.agec.ntu.edu.tw/ecmeeting/01/C1-1-040.pdf], accessed on 1 May 2015.

Taylor, A. M., Taylor M. P. (2004). The Purchasing Power Parity Debate. Journal of Economic Perspectives, 18(4), 135-158.

Taylor, M. P. (2006). Real Exchange Rates and Purchasing Power Parity: Mean-Reversion in Economic Thought. Applied Financial Economics, 16(1-2), 1-17, https://doi.org/10.1080/09603100500390067

Zhou, S., Kutan, A. M. (2011). Is the Evidence for PPP Reliable? A Sustainability Examination of the Stationary of Real Exchange Rates. Journal of Banking \& Finance, 35(9), 2479-2490, https://doi.org/10.1016/j.jbankfin.2011.02.006 